\title{
KRITINIAI ELEKTRONINĖS KOMERCIJOS PROJEKTU SĖKMĖS VEIKSNIAI
}

\author{
Jolanta SABAITYTE், Guoda ČERNIAUSKAITE்* \\ Vilniaus Gedimino technikos universitetas, Verslo vadybos fakultetas, \\ Verslo technologiju ir verslininkystès, Saulètekio al. 11, LT10223 Vilnius, Lietuva \\ *El.paštas guoda.cerniauskaite@ stud.vgtu.lt
}

\begin{abstract}
Santrauka. Interneto vartotojų skaičius visame pasaulyje sparčiai auga. Per pastaruosius 19 metų šis skaičius išaugo nuo 360983512 iki 4536248808 vartotojų, kas rodo ypatingai spartų augimą. Elektroninè komercija tampa potencialia sritimi verslo vystymui bei sukuria didelę pridètinę vertę pasaulinei ekonomikai. Didèjanti pasiūla vartotojui sukuria terpę būti išrankiam. Tokiu būdu didẻja konkurencija tarp elektroninės komercijos platformu ir tampa sunkiau išlikti sèkmingais. Šio straipsnio tikslas - identifikavus veiksnius, lemiančius elektroninès komercijos projektu sëkmę, sukurti koncepcinị elektroninès komercijos sẻkmės modelį. Veiksnių identifikavimui buvo atlikta mokslinès literatūros analizè. Ivertinus egzistuojančius sèkmės veiksnius ir sèkmès modelius buvo nustatyti trūkumai ir suformuotas e.komercijos sėkmės modelis, kuris ịtraukia kartų skirtumą kaip faktoriu, kuris nulemia vartotojo pasirinkimą.
\end{abstract}

Reikšminiai žodžiai: informacinès technologijos, e. komercija, e. komercijos projektas, e. komercijos sèkmès modelis, sèkmès veiksniai.

\section{Ivadas}

Sparčiai tobulëjančių informacinių ir komunikaciniu technologijų raida sukèlè pokyčius tradicinio verslo pasaulyje. Mobiliujų duomenų perdavimo technologija paskatino aktyvią eletroninių verlsų plètotę (Cristofaro, 2019). Interneto ir informacinių technologijų revoliucija sukūrè sąlygas ịmonèms kurti naujas struktūras, kurios sujungia verslą su vartotoju, tiekèjais bei kitomis valstybès institucijomis. Remiantis pasaulinès interneto statistikos (Miniwatss marketing group, 2019) duomenimis interneto naudotoju skaičius per paskutinius 19 metu išaugo $1156,64 \%$. Remiantis pasaulinès skaitmeninès revoliucijos duomenimis (Kinda, 2019) lyderiaujanti valstybè elektroninio verslo platformu skaičiaus atžvilgiu yra Kinija. Nuo elektroninès komercijos atsiradimo Kinijos dalis pasaulinëje elektroninès prekybos mažmeninių sandorių vertèje išaugo nuo mažiau nei $1 \%$ iki daugiau nei $50 \%$. Pasaulinès elektroninès komercijos apyvarta, įskaitant ir el. paslaugas, $2019 \mathrm{~m}$. pasaulyje sudare 3,53 trilijonus JAV dolerių ir yra prognozuojama, jog iki $2022 \mathrm{~m}$. prekybos pajamos išaugs iki 6,54 trilijonų JAV dolerių (Clement, 2019). Analizuojant statistinius duomenis akivaizdu, jog elektroninè komercija yra auganti, potenciali sritis, sukurianti didelę pridètinę vertę pasaulinei ekonomikai. Tačiau augant elektroninės komercijos potencialui auga ir konkurencija. Teigiama, jog $90 \%$ elektroninio verslo startuolių žlunga per pirmąsias 120 realizacijos dienų, o likusiems $10 \%$ pavyksta sukurti sékmingą elektroninès komercijos verslą (Rigby, 2019). Tokị mažą procentą lemia svarbūs faktoriai, tokie kaip: vadovo žinios ir kompetencija, tinkamų gamintojų pasirinkimas, prekès ženklo žinomumas, sistemos efektyvumas bei saugumas, esamos rinkos analizės bei nuolatinis žinių rinkimas ir tobulejjimas (Choshin, 2017; Wang et al., 2019, and Dasuki, 2018).

Nagrinėjant mokslinę literatūrą galima pastebèti, jog elektroninès komercijos sèkmę gali nulemti daugybė tarpusavyje koreliuojančių veiksnių (Abdullah et al., 2019). Vieni mokslininkai analizuodami elektroninès komercijos sėkmès faktorius remiasi H. Delone ir R. McLean informaciniu sistemu sékmès modeliu (Roky ir Meriouh, 2015; Delone ir McLean, 2003; Wang et al., 2019; Dasuki, 2018). Šie mokslininkai akcentuoja aštuonis pagrindinius faktorius: sistemos kokybė, informacijos naujumas, paslaugų kokybė, sistemos naudojimo dažnumas, naudojamumo tikslai, vartotojo pasitenkinimas, individualus poveikis ir organizacinis poveikis. Tuo tarpu kiti mokslininkai labiau akcentuoja logistikos paslaugų kokybę, internetinio puslapio kokybę, funkcionalumą, saugumą bei patikimumą (Abdullah et al., 2019; Jagannathan et al., 2018, and Lin et al., 2016). Tačiau pastebètina, kad trūksta informacijos analizuojant skirtingų kartų vartotojų poreikius ir jų priimamus sprendimus, apsipirkimo metu, elektroninès komercijos platformose. 
Šio straipsnio tikslas - identifikuoti svarbiausius kritinius veiksnius lemiančius e. komercijos projektų sèkmę, teikiant paslaugas X ir Y kartų atstovams ir sukurti elektroninès komercijos koncepcinį sèkmès modelį. Siekiant tikslo buvo išsikelti šie uždaviniai:

- išanalizuoti ir apibrèžti elektroninès komercijos sampratą;

- išanalizuoti esamus elektroninès komercijos sèkmès veiksnius ir jų klasifikacijas;

- ívertinti X ir Y kartų skirtumus nulemiančius sprendimo prièmimą pirkti virtualioje platformoje;

Siekiant darbo tikslo naudoti metodai: mokslinių ir metodinių šaltinių analizè, informacijos sisteminimas. Mokslinio tyrimo objektas: elektroninès komercijos projektų sėkmės veiksniai.

\section{Elektroninès komercijos samprata ir koncepcija}

Tradicinį verslo pasauli kardinaliai pakeitè informacinių ir komunikacinių technologijų inovacijos. XX a. paskutinis dešimtmetis atvėrè kelią naujovėms, skatinančioms globalizaciją. Elektroninė komercija per pastarajị dešimtmetį patyrė didelị ekonomini augimą visame pasaulyje. İtakos tam turèjo besivystančios informacinès technologijos, kintanti socialinė ir ekonominė aplinka bei žmonių asmeninis tobulèjimas (Kabbaj, 2018). Kiekvienais metais mažiausiai 1 bilijonas pasaulio vartotojų perka prekes ir paslaugas internetu. Statistika rodo, jog iki $2021 \mathrm{~m}$. galima tikètis, jog šis vartotojų skaičius išaugs iki 2,16 bilijono pirkèjų per metus (Clement, 2019). Toks spartus augimas lemia, jog elektroninė komercija, yra plačiai nagrinejjama mokslininkų ir tyrèjų.

Dauguma tyrèjų (Angelina et al., 2019; Abdullah et al., 2019; ir Shaw, 2014) apibrèždami sąvoką ,elektroninė komercija“" akcentuoja skirtingus aspektus, tokius kaip verslo modelis, verslo metodika, verslo informacijos mainai. Mokslininkai (Angelina, Hermawan, ir Suroso, 2019) teigia jog elektroninè komercija yra interneto naudojimas verslo tikslams, dažnai nulemiantis komercinių sandorių tarp organizacijos ir vartotojo sudarymą. Pasak Abdullah et al. (2019) elektroninę komerciją galima apibrèžti kaip modernią verslo metodiką skirtą organizacijoms, prekybininkams ir vartotojams, siekiant sumažinti išlaidas, bet tuo pačiu pagerinti prekių ir paslaugų kokybę bei padidinti paslaugų teikimo spartą. Anot Shaw (2014) elektroninè komercija yra verslo informacijos mainai, verslo ryšių palaikymas ir verslo operacijų vykdymas telekomunikacijų tinklais.

Akcentuojant virtualią erdvę elektroninė komercija apibrèžiama kaip neribotų galimybių platforma egzistuojanti internete, o fizinis verslas apibrèžiamas kaip ribotų galimybių (Ward et al., 2016, žr. Azam, 2012). Elektroninė komercija yra visos verslo procesų grandinès realizavimas naudojant telekomunikacines ir informacines technologijas, tokiu būdu igyvendinant verslo tikslus (Santos et al., 2017). Mehra ir Khurana (2015) elektroninę komerciją apibrezžia kaip kompiuterio, interneto ir programinès įrangos naudojimą produkto pardavimui. Taip pat pasiūlymo, užsakymo, sąskaitos faktūros ir kitų duomenų siuntimui, reikalingų klientams, tiekejjams ar darbuotojams.

Išsamiai elektroninę komerciją apibrěžia (Bhat, 2016): elektroninè komercija yra elektroninių ryšių ir skaitmeninès informacijos apdorojimo technologijos naudojimas verslo operacijose, siekiant sukurti, pertvarkyti ir iš naujo apibrěžti vertès kūrimo ryšius tarp organizacijų ir tarp organizacijų ir individų. Išanalizavus įvairių mokslininkų pateiktus apibrëžimus, 1 lentelejje pateikiamos moksliniuose darbuose sutinkamos elektroninès komercijos sampratos.

1 lentelè. Elektroninès komercijos sampratos (sudaryta autorių)

\begin{tabular}{|c|c|}
\hline Autorius & Elektroninės komercijos sampratos \\
\hline Shaw (2014) & $\begin{array}{l}\text { Elektroninė komercija yra verslo informacijos mainai, verslo ryšių palaikymas ir verslo } \\
\text { operacijų vykdymas telekomunikacijų tinklais. }\end{array}$ \\
\hline $\begin{array}{l}\text { Ward, Sipior ir Volonino } \\
(2016)\end{array}$ & $\begin{array}{l}\text { Elektroninė komercija apibrėžiama kaip neribotų galimybių platforma egzistuojanti } \\
\text { internete, o fizinis verslas apibréžiamas kaip ribotų galimybių. }\end{array}$ \\
\hline Bhat (2016) & $\begin{array}{l}\text { Elektroninė komercija - elektroninių ryšių ir skaitmeninės informacijos apdorojimo } \\
\text { technologijos naudojimas verslo operacijose, siekiant sukurti, pertvarkyti ir iš naujo } \\
\text { apibrěžti vertès kūrimo ryšius tarp organizacijų ir tarp organizacijų ir individų. }\end{array}$ \\
\hline Santos et al. (2017) & $\begin{array}{l}\text { Elektroninė komercija yra visos verslo procesų grandinės realizavimas naudojant } \\
\text { telekomunikacines ir informacines technologijas, tokiu būdu igyvendinant verslo tikslus. }\end{array}$ \\
\hline Mehra ir Khurana (2015) & $\begin{array}{l}\text { Elektroninè komercija tai kompiuterio, interneto ir programinès ịrangos naudojimas } \\
\text { produkto pardavimui. Pasiūlymo, užsakymo, sąskaitos faktūros ir kitų duomenų siuntimui } \\
\text { reikalingų klientams, tiekėjams ar darbuotojams. }\end{array}$ \\
\hline Abdullah et al. (2019) & $\begin{array}{l}\text { Elektroninę komerciją galima apibrèžti kaip modernią verslo metodiką skirtą } \\
\text { organizacijoms, prekybininkams ir vartotojams, siekiant sumažinti išlaidas, bet tuo pačiu } \\
\text { pagerinti prekių ir paslaugų kokybę bei padidinti paslaugų teikimo spartą. }\end{array}$ \\
\hline $\begin{array}{l}\text { Angelina, Hermawan ir } \\
\text { Suroso (2019) }\end{array}$ & $\begin{array}{l}\text { Tai yra interneto naudojimas verslo tikslams, dažnai nulemiantis komercinių sandorių tarp } \\
\text { organizacijos ir vartotojo sudarymą. }\end{array}$ \\
\hline
\end{tabular}


Analizuojant šiuos apibrèžimus galima teigti, kad e. komercija apima ịvairius verslo procesus vykdomus internete bei realizuoja visą paslaugų tiekimo grandinę. Todèl toliau šiame straipsnyje remiamasi tokiu apibrèžimu: elektroninè komercija - modernus verslo modelis, paremtas interneto ir informacinių technologijų naudojimu, verslo procesams igalinti skaitmeninejje erdvejje.

Stipriai išaugusi elektroninè komercija pakeitė nusistovėjusias tradicinio verslo taisykles ir atvėrè naujas galimybes verslo plètrai. Elektroninè komercija suteikia galimybę atlikti daugybę sandorių, kurie sudaromi elektroniniu būdu tarp įmonių, vartotojų bei valdžios organų (Santos et al., 2017). 2 lentelèje pateiktos elektroninès komercijos rūšys pagal sandorių sudarymo galimybę. Remiantis skirtingais prekybos santykių tipais tarp šalių elektroninę komerciją galima suskirstyti ị skirtingus modelius: B2B, B2C, C2B, C2C ir mobili komercija (Bhalekar et al., 2015).

- Verslas - verslui (B2B) tai elektroninès komercijos modelis, apimantis elektroninius sandorius tarp bendrovių užsiimančių verslu ir teikiančias paslaugas viena kitai. Dažnai tai būna gamintojai, parduodantys produktus atstovams arba didmenininkai parduodantys prekes mažmenininkams. Kainos dažnai nustatomos atsižvelgiant ị užsakomą kiekị (Bhalekar et al., 2015).

- Verslas - vartotojui (B2C) šis modelis taikomas bet kokiam verslui ar organizacijai, kuri parduoda savo paslaugas arba gaminius vartotojams internetu (Shaw, 2014).

- Vartotojas - verslui (C2B) yra toks elektroninès komercijos modelis, kuriame vartotojai sukuria tam tikrą vertę (produktą), o verslo organizacijos naudojasi sukurta verte (Dhana Lakshmi ir Shayena, 2018). Autorius K.R. Lakshmi (2018) teigia, kad šis verslo modelis yra panašus ị atvirkštinị aukcioną, kuomet pirkejjas turi galimybę nurodyti savo norimą kainą.

- Vartotojas - vartotojui (C2C) modelyje pirkèjas ir pardavèjas nèra tiesioginiai verslininkai, bet pardavimo sandoriai yra vykdomi. Dažniausiai tokiuose komerciniuose santykiuose dalyvauja trečioji šalis, kaip pavyzdys - internetinis aukcionas (Babenko et al., 2019).

- Mobili komercija (angl. M-commerce) šis elektroninès komercijos modelis išryškejjo tuomet, kai mobilieji duomenys tapo pasiekiami beveik visose pasaulio vietose. Mobilieji telefonai, nešiojami kompiuteriai, skaitmeniniai laikrodžiai ar automobiliai naudojasi bevieliu tinklu (Shaw, 2014). Naudojantis programine įranga galim automatizuoti ir supaprastinti pardavimo bei paslaugų gavimo procesus (Babenko et al., 2019).

2 lentelè. Elektroninès komercijos modeliai (Santos et al., 2017)

\begin{tabular}{|l|l|l|}
\hline \multicolumn{1}{|c|}{ Žymuo } & \multicolumn{1}{|c|}{ Pavadinimas } & \multicolumn{1}{c|}{ Apibūdinimas } \\
\hline B2B & Verslas - verslui & Sandoris tarp įmonių \\
\hline B2C / C2B & Verslas - vartotojui / Vartotojas - verslui & $\begin{array}{l}\text { Sandoris tarp bendrovès ir galutinio vartotojo / } \\
\text { Sandoris tarp vartotojo kuriančio vertę verslui ir } \\
\text { bendrovès }\end{array}$ \\
\hline C2C & Vartotojas - vartotojui & Sandoris tarp vartotojų \\
\hline G2C / C2G & $\begin{array}{l}\text { Vyriausybe் - vartotojui / Vartotojas - } \\
\text { vyriausybe் }\end{array}$ & $\begin{array}{l}\text { Sandoris tarp vyriausybės ir gyventojų / sandoris tarp } \\
\text { individo ir vyriausybės }\end{array}$ \\
\hline B2G / G2B & Verslas - vyriausybei / vyriausybè - verslui & Sandoriai tarp verslo ir vyriausybės. \\
\hline G2G & Vyriausybe் - vyriausybei & Sandoriai tarp valstybinių institucijų \\
\hline
\end{tabular}

Elektroninė komercija suteikia galimybę organizacijai pasiekti platesnę, tarptautinę rinką, tam panaudojus minimalias investicijas (A. Y. Vadwala ir M. S. Vadwala, 2017). Kaip teigia A. Y. Vadwala ir M. S. Vadwala (2017) organizaciją besinaudojančią elektroninės komercijos verslo modeliu, daug lengviau pasiekia didesnis klientų srautas viso pasaulio mastu. Dar vienas svarbus elektroninès komercijos privalumas tai, jog produkcija ir paslaugos yra pasiekiamos 24/7, neribojant darbo valandų organizacijos pelnas dideja (Franco ir Regi, 2016). E. komercijos modelis padeda verslo organizacijoms sumažinti išlaidas susijusias su įvairių procesų kūrimu, organizavimu ir igalinimu popieriniuose ištekliuose, visus šiuos procesus skaitmenizuojant (A. Y. Vadwala ir M. S. Vadwala, 2017).

Elektroninė komercija kaip verslo modelis yra naudinga ne tik verslo organizacijoms, bet ir patiems vartotojams. Lankstumas ir efektyvumas - vieni iš pagrindinių šio verslo modelio aspektų suteikiančių naudą vartotojui. Vartotojai efektyviai gali gauti bet kokią reikiamą informaciją apie produktą ar paslaugą ir jiems nebūtina išvykti iš namų tam, kad būtų ìvykdytas verslo sandoris (Yadiati ir Meiryani, 2019). Anot A. Y. Vadwala ir M. S. Vadwala (2017) elektronine komercija suteikia vartotojui galimybę rinktis ir lyginti produktus bei paslaugas, tokiu būdu auginama konkurencija tarp organizacijų ir viso to rezultate vartotojai gauna nuolaidas, dovanų kuponus produktams ir paslaugoms. 


\section{Tyrimo metodika}

Šio straipsnio tyrimas sutelktas ị elektroninès komercijos sẻkmès faktorius. Siekiant šio straipsnio tikslo yra atliekama literatūros analizè, informacinių sistemų sėkmės modelių analizė, skirtingų kartų vartotojų poreikių ir elgsenos analizè bei sisteminami literatūroje esantys duomenys ir tyrimų rezultatai. Formuojamas koncepcinis elektroninès komercijos sèkmès veiksnių modelis, sudarytas iš vienuolikos skirtingų komponentų: kartų skirtumas, informacijos kokybè, sistemos kokybé, kibernetinis saugumas, funkcionalumas, paslaugu kokybe், produkto kokybè, kainos tinkamumas, pasitikejjimas, vartotojo pasitenkinimas, grynoji nauda.

Tyrimas atliekamas pagal šiuos punktus:

- Literatūros analizè. Literatūros apžvalga buvo atlikta siekiant apibrèžti elektroninès komercijos sąvoką, išskirti jos privalumus, apžvelgti skirtingų kartų vartotojų poreikius bei elgesenę apsipirkimo metu ir taip pat susiteminti literatūroje pateiktus kritinius elektroninès komercijos sèkmès faktorius.

- Elektroninès komercijos sèkmès veiksnių analizè. Analizè atlikta remiantis literatūroje rastais DirM informacinių sistemų sèkmès modeliu, technologijų prièmimo modeliu (TAM), pagrịsto veiksmo teorijos modeliu (TRA).

-Elektroninès komercijos sèkmès veiksniu koncepcinio modelio kūrimas. Modelis (žr. 5 paveikslą) sukurtas remiantis patobulintu D\&M informacinių sistemų modeliu. Remiantis literatūroje rastais skirtingų kartų vartotojų poreikiais buvo išskirtas esminis modelio komponentas - kartų skirtumas.

Dauguma naujausių tyrimų siejami su pasitikẻjimu bei vartotojų elgsena. Literatūroje trūksta informacijos apie skirtingų kartų vartotojų poreikius. Todèl šis tyrimas, praplečia elektroninės komercijos sẻkmès veiksnių tyrimų sritị.

\section{Elektroninès komercijos sèkmès veiksniai}

Galima teigti, kad elektroninè komercija yra informaciniu ir komunikaciniu technologijų naudos ekonomikai ịrodymas. Informacinių sistemų technologijų naudojimas palaiko ekonomikos augimą ir plètrą, padidina komercini efektyvumą ir palengvina šalių tarpusavio bendradarbiavimą (Choshin ir Ghaffari, 2017). William DeLone ir Ephraim McLean (D\&M) informaciniu sistemų sèkmès modelis buvo sukurtas nustatyti pagrindinius veiksnius nulemiančius IS sèkmę (Roky ir Meriouh, 2015). Šie mokslininkai išanalizavo ir integravo ankstesnius IS empirinius efektyvumo tyrimus ir apibendrindami sukūre naują IS sėkmės modelį (Wang et al., 2019). D\&M IS sėkmés modelis (žr. 1 paveikslą) pateikia šešis pagrindinius veiksnius ir jų tarpusavio ryšius: sistemos kokybè, informacijos kokybè, sistemos naudojimas, vartotojų pasitenkinimas, individualus poveikis, organizacinis poveikis. Sistemos kokybė ir informacijos kokybè daro ịtaką sistemos naudojimu, o tai lemia vartotojų pasitenkinimą, aktyvumą bei organizacini našumą (Wang et al., 2019).

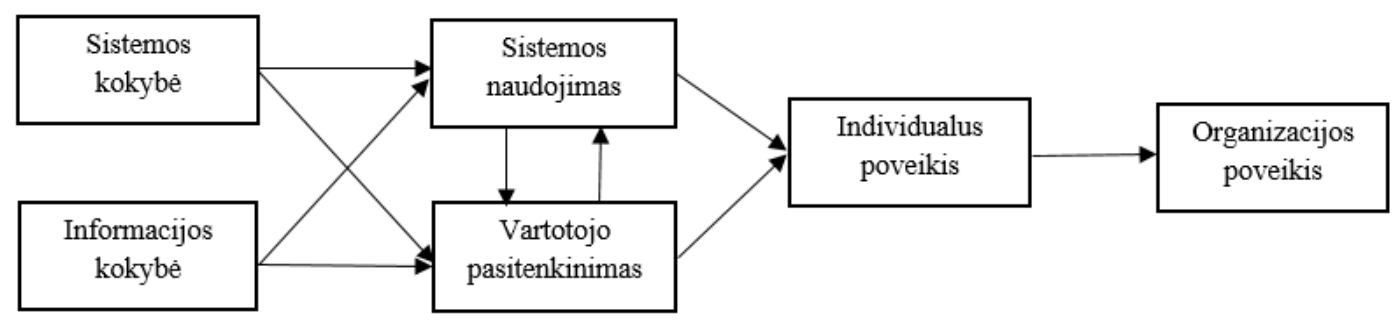

1 paveikslas. D\&M IS sèkmès modelis (DeLone ir McLean, 2016)

Patobulintas DeLone ir McLean IS sékmès modelis (žr. 2 paveikslą) buvo pritaikytas elektroninės komercijos projektams (Dasuki, 2018). Atsižvelgus ị vartotojų poreikius buvo parinkti šeši sẻkmès veiksniai: informacijos kokybè, sistemos kokybe், paslaugų kokybè, naudos suvokimas, vartotojų pasitenkinimas, IS naudojimas/ketinimas naudoti (Wang et al., 2019). Tyrimų, kuriuose buvo naudojamas patobulintas D\&M IS sékmės modelis rezultatai nebuvo vienodi. Taikant ši modeli internetinei elektroninès komercijos platformai buvo nustatyta, kad sistemos kokybė ir informacijos kokybė buvo pagrindiniai rodikliai lemiantys vartotojų pasitenkinimą (Dasuki, 2018). Tuo tarpu Jagannathan et al. (2018) pastebëjo, kad internetinès bankininkystès platformos sèkmei įtakos neturèjo sistemos kokybè, tačiau lemiantis veiksnys vartotojų pasitenkinimui buvo - informacijos kokybė ir saugumas. Skirtingi rezultatai rodo tai, kad modelis gali būti lanksčiai pritaikytas ịvairiose elektroninès komercijos srityse.

Analizuojant kritinius veiksnius, nulemiančius elektroninės komercijos sẻkmę, svarbu atkreipti dėmesị ne tik ị technologinius ir aplinkos veiksnius, bet būtina išanalizuoti vartotoją ir jo poreikius, bei elgseną apsipirkimo metu. Tobulèjant IS tolygiai tobulèja ir skaitmeninės apsipirkimo platformos. Pardavejai pasiūlo vis daugiau galimybiu pirkimo procese bei teikia vis kokybiškesnes paslaugas ir produktus (Pappas, 2018). Dèl šių priežasčių ir nuolatinio tobulëjimo svarbu suprasti priežastis dèl kurių klientai pasirenka apsipirkimus elektroninèse platformose bei juos motyvuojančius veiksnius (Fedorko et al., 2018). Kitaip tariant vartotojų elgsenos analizė ir jų poreikių supratimas yra pagrindinis elektroninès komercijos sėkmės aspektas. 


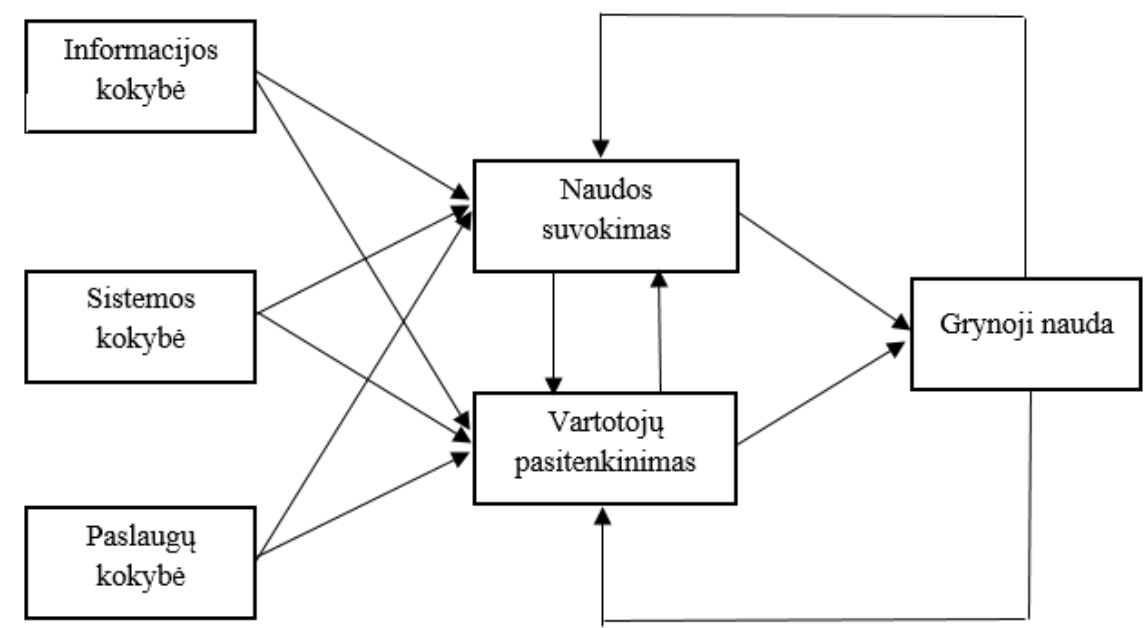

2 paveikslas. Patobulintas D\&M IS sėkmès modelis (DeLone ir McLean, 2016)

Elektroninès komercijos platformos siekia, kad vartotojas pirmojo apsilankymo metu, naudodamasis visomis funkcijomis patirtų tik teigiamą patirtị ir nepajaustų frustracijos (Fedorko et al., 2018). Tiriant vartotojų elgseną IS aplinkoje plačiai taikomas technologijų priëmimo modelis (angl. Technology Acceptance Model, TAM). Šis modelis (žr. 3 paveikslą) apibrèžia ịvairius veiksnius susijusius su naujujų technologijų prièmimu ir noru tobulèti technologiju srityje, vartotojų atžvilgiu. Požiūris ị vartojimą nusako vartotojų norą naudoti tam tikrą technologiją bei technologijos paprastumą (Guzzo et al., 2016). TAM modelis kyla iš išorinių vartotojų veiksnių, susijusių su individualiais isitikinimais ir asmeninemis nuostatomis (Dakduk et al., 2017). Teigiama, jog vartotojas suvokia apie tikimybę, kad naujų technologijų naudojimas padès pagerinti apsipirkimo kokybę ir atlikti visas funkcijas greičiau bei paprasčiau. Bet tuo pačiu vartotojas siekia, jog visos naujos funkcijos bei technologijos būtų lengvai suvokiamos (Dakduk et al., 2017).

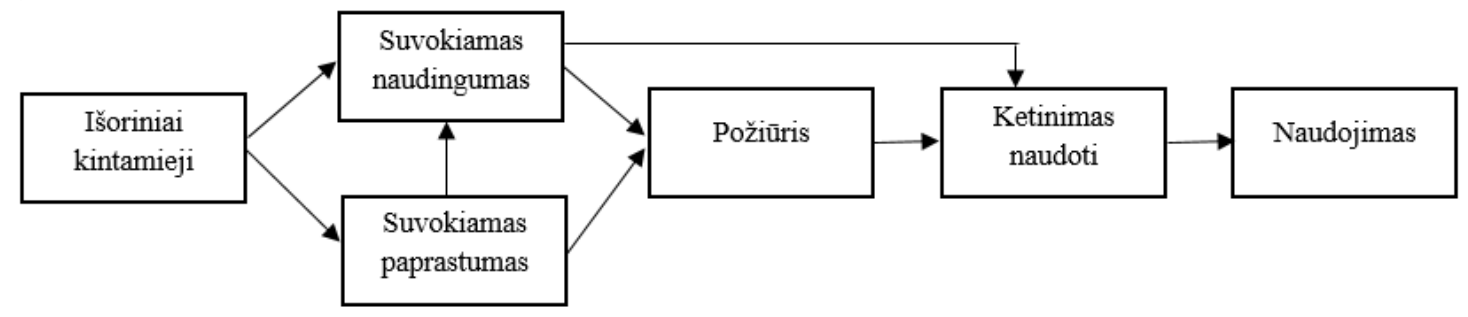

3 paveikslas. Technologijų prièmimo modelis TAM (Dakduk et al., 2017)

Analizuojant vartotojo elgseną dažnai yra naudojama pagristo veiksmo teorijos modelis TRA (angl. Theroy of Reasoned Action, TRA). Šis modelis (žr. 4 paveikslą) naudojamas tam, kad būtų suprastas ir išmatuotas ryšys tarp vartotojo asmeninio požiūrio, intencijų ir elgesio. TRA teorija teigia, jog žmonės lengvai priima paprastus sprendimus naudodamiesi jiems lengvai ir greitai prieinama informacija (Solangi et al., 2018).

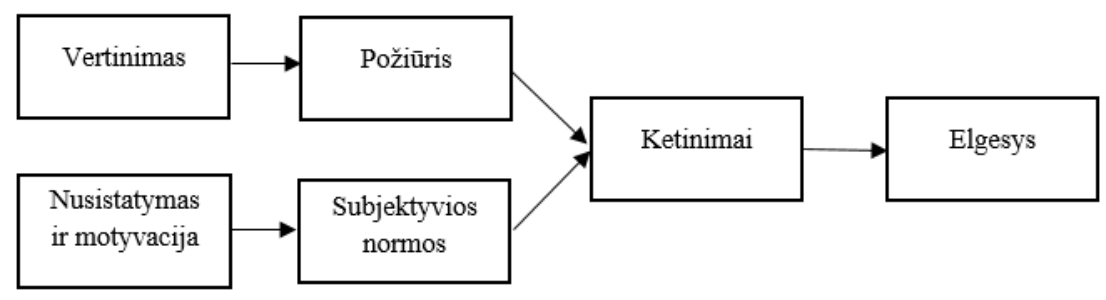

4 paveikslas. Pagristo veiksmo teorijos modelis TRA (Solangi et al., 2018)

TAM ir TRA modeliai yra tarpusavyje susiję. Atsiranda ryšys tarp vartotojų ịsitikinimo apie technologiju naudingumą ir tarp ketinimų naudoti technologijas. Iš to išplaukia du pagrindiniai veiksniai: suvoktas naudingumas ir suvoktas naudojimosi paprastumas. Visa tai nulemia tam tikros technologijos ar sistemos naudojimą (Ramadiani et al., 2017).

Analizuojant elektroninès komercijos sèkmès veiksnius, literatūroje galima rasti įvairių klasifikacijų skirtu sugrupuoti sėkmės veiksnius i tam tikras kategorijas. Pasak Choshin ir Ghaffari (2017) norint sėkmingai vystyti elektroninès komercijos projektus svarbu atsižvelgti i pirminius veiksnius, tokius kaip: detalus verslo modelis, 
optimalus turimų išteklių panaudojimas bei klientų poreikių analizè. Literatūroje randama ịvairių autorių pateiktų sèkmès veiksnių klasifikacijų. Svarbiausi elektroninès komercijos sėkmès veiksniai tiesiogiai priklausomi nuo IS technologijų ir interneto skirstomi ị šias kategorijas (Choshin ir Ghaffari, 2017, žr. Dyerson et al., 2009):

- Kvalifikaciniai veiksniai: vadovo žinios ir patirtis, darbuotojų kompetencija, klientų sąmoningumas;

- Aplinkos veiksniai: įstatymai valstybejje, rinkos platumas, gamintojų bei tiekejų pasirinkimas;

- Žmogiškieji veiksniai: vidinių išteklių prieinamumas ir panaudojimas, specialistų paklausa;

- Technologiniai veiksniai: internetinis saugumas, technologiniai ištekliai ir programine ịranga.

Moksliniuose tyrimuose taip pat galima rasti alternatyvią elektroninės komercijos sèkmès veiksnių klasifikaciją (Choshin ir Ghaffari, 2017, žr. Ramanathan et al., 2012):

- Veiklos veiksniai: klientų pasitenkinimas, procesų tobulinimas ir konkurencingumas;

- Rinkodaros veiksniai: internetinè reklama, klientų sąmoningumas ir prekès ženklo žinomumas;

- Technologiniai veiksniai: nuolatinis kokybès ir komunikacijos gerinimas, internetinis saugumas, paprastas internetinio puslapio dizainas, išsami ir greitai pasiekiama informacija.

Elektroninès prekybos sẻkmès „matavimo“ metodai skiriasi nuo fizinių paslaugų rinkos sẻkmès metodų analizavimo. Todèl e-paslaugų kokybė apibrèžiama kaip bendras klientų pasitenkinimas paslaugų kokybe virtualioje rinkoje (Varela et al., 2017). Literatūroje (Varela et al., 2017, žr. Kawasaki, 2004) vyrauja nuomonè, jog internetinės svetainès/platformos dizainas, išpildymas, patikimumas (saugumo ir privatumo politika) ir klientu aptarnavimo spartumas yra lemiantys veiksniai kliento lojalumui. Taip pat nustatyta, kad veiksniai (pvz.: sklandus IS programų darbas, savo profesiją išmanantys darbuotojai, saugumo užtikrinimas virtualioje erdvèje, efektyvi komunikacija tinkle) susiję su efektyviu informacinių sistemų naudojimu užtikrina sèkmingą elektroninès komercijos projekto vykdymą ( Choshin ir Ghaffari, 2017, žr. Fathian et al., 2008).

\section{4. $X$ ir Y kartų skirtumus nulemiantys veiksniai}

Literatūroje analizuojančioje elektroninès komercijos sėkmės veiksnius galima pastebėti jog dažniausiai yra nagrinejjamos sąsajos tarp aplinkos veiksnių, technologinių faktorių ir vartotojų poreikių (Varela et al., 2017; Kawasaki, 2004; Choshin ir Ghaffari, 2017; Wang et al., 2019; Dasuki, 2018; DeLone ir McLean, 2016; Fedorko et al., 2018; Dakduk et al., 2017). Literatūroje nėra pakankamai daug informacijos, kuri būtų susijusi su skirtingo amžiaus (skirtingų kartų) vartotojų elgesiu bei pasirinkimais naudojantis elektroninės komercijos platformomis. Dèl amžiaus pokyčių vyresnio amžiaus vartotojų sprendimų prièmimo procesai ir įpročiai skiriasi nuo jaunesnių vartotojų (Benjamin et al., 2016). Informacijos apdorojimo teorija aiškina, kad vyresnio amžiaus vartotojai yra mažiau linkę ieškoti papildomų duomenų apie prekę ar spręsti iškilusius nesklandumus remdamiesi naujausiomis technologijomis (Benjamin et al., 2016). Jų pirkimas paremtas paprastumu. Pirkėjai turintys daugiau apsipirkimo internete patirties, sugeba priimti sprendimus, turèdami mažiau informacijos. Tai rodo, jog brandaus amžiaus vartotojai, priimdami sprendimus dèl pirkimo, gali naudoti paprastesnị kriterijų rinkinį, bet tuo pačiu ir mažiau pasitiki elektroninès komercijos paslaugomis. Priešingai, jaunesni pirkèjai jaučiasi laisviau ir drąsiai naudojasi visomis paieškos galimybėmis, lygina rinkoje esančią panašią produkciją, prieš priimdami sprendimą.

Skirtingas gimimo laikas natūraliai skirsto žmones ị atskiras socialines grupes. Literatūroje teigiama, kad žmones, kuriuos sieja bendras gimimo laikotarpis ir tuomet vyravusi istorinè erdvè, suteikia jiems kolektyvinę asmenybę (Ramírez-Correa et al., 2019). Ši sąvoka, kolektyvinė asmenybė, naudojama rinkodaroje indentifikuojant skirtingas kartas. Jos klasifikuojamos nuo 1900 m. 20 metų periodais. Kartos skirstomos ị: G1, tylioji karta, kūdykių bumo karta, X karta, Y karta ir Z karta prasidejusi nuo 2003 m. (Ramírez-Correa et al., 2019).

$\mathrm{X}$ kartos atstovai yra vartotojai gimę iki devintojo dešimtmešio pabaigos. Literatūroje pažymima, jog ši karta dar yra vadinama „baimės karta“, nes jiems teko išgyventi ekonomines krizes, branduolinius karus bei darbo vietų stygių (Chaney et al., 2017). Šie veiksniai gali paaiškinti X kartos skeptiškai vertinamus rinkodaros stimulus, todėl šiuo segmentu sunkiau manipuliuoti ir įtikinti vartotojus (Chaney et al., 2017). Y kartos atstovai užaugo lydimi interneto ir naujujų technologijų. Informacijos vystymosi eroje ir kylant socialiniams tinklams šių vartotojų kasdienybė tapo neatsiejama nuo interneto, daug įtakos jų veiksmams turi tinklo kultūra (Lee ir Lee, 2020).

Anot Lee ir Lee (2020) Y kartos vartotojams būdinga stipri nepriklausomybè, suasmenintos vartojimo koncepcijos, jų nebeveikia baimès ir valdžios hierarchija, jie dalijasi ir skleidžia informaciją apie produktus ir naujus prekès ženklus.

Tyrinejjant elektroninès komercijos sėkmès faktorius buvo pastebėta, jog X ir Y kartų skirtumai ir specialieji bruožai būdingi tam tikrai kartai, gali būti susiję su vartotojo sprendimu pirkti produktą ar paslaugą (Ramírez-Correa et al., 2019). Ross-Cortes et al. (2016) atliktas tyrimas parodo, jog X kartos atsovams naudojantis elektroninès komercijos platformomis, galutiniam sprendimui įtakos turi kitų vartotojų išsakyta nuomonè, o Y kartai priklausantiems asmenims tai nèra svarbu. Jie pasitiki savo sprendimais ir nenori būti priklausomi nuo kitų nuomonès. Analizuojant literatūrą taip pat galima pastebèti vyraujantị terminą: kartų rinkodara. Tokio tipo rinkodara susideda iš prekių ar paslaugų pasiūlos pritaikytų konkrečiai vienai kartai (Chaney et al., 2017). Pasak Chaney et al., (2017) naudojant kartų rinkodaros strategiją elektroninès komercijos platformos orientuojasi ị tokius produktus, kurie 
tiesiogiai siejasi su pasirinkta karta, stengiamasi atspindèti kartos vertybes. Bet tai atspindi tik siaurią pasiūlos dalị ir negali užtikrinti masinio pirkimo.

Išryškèja labai stiprus santykis tarp skirtingų kartų atstovų ir informacinių bei komunikacinių technologijų. Kiekvienos kartos sanktykis su žiniasklaida ir internetu daro įtaką elektroninès komercijos strategijoms ir veiksnumui (Chaney et al., 2017, Wang, 2008). Internetas ir mobilioji reklama šiuo metu atrodo pats perspektyviausias reklamos tipas, tačiau tyrimai rodo, kad tokio reklamos tipo pripažinimas ir priëmimas skirtingoms kartoms skiriasi (Chu ir Sung, 2015). Santykis su televizija skirtingoms kartoms taip pat yra nevienodas. Elektroninès komercijos platformos bandydamos pasiekti vartotojo per televiziją, neabejotinai turi naudoti ir socialinius tinklus, kadangi tiek Y, tiek Z karta pirmumą teikia socialinių tinklų reklamoms nei, kad televizijai (Chaney et al., 2017). Šiuo metu Y karta sudaro didžiausią perkamąą galią internetu, todèl šios kartos atstovai dažniausiai tampa svarbiausiais klientais elektroninès komercijos platformose (Chakraborty ir Balakrishnan, 2017). Bet žvelgiant iš kitos pusès X kartos atstovai yra tie vartotojai, kurie šiuo metu generuoja pačias didžiausias pajamas ir jų išlaidos yra didžiausios, bet apsipirkimams $\mathrm{X}$ kartos atstovai dažnai pasirenka fizines parduotuves (Wang et al., 2019). Būtent dèl šios priežasties verta akcentuotis tiek ir ị X, tiek ir į Z kartų atstovus. Elektroninès komercijos platformos turètų tobulinti savo verslo modelius bei skaitmenines platformas atsižvelgiant $i$ abiejų kartų poreikius.

Remiantis aukščiau pateikta literatūros analize buvo išskirta daug elektroninės komercijos sèkmès veiksnių. Šie veiksniai aptariam identifikuojant atskirai po vieną arba bendromis grupemis iš tam tikrų perspektyvų (Varela et al., 2017; Kawasaki, 2004; Choshin ir Ghaffari, 2017; Wang et al., 2019; Dasuki, 2018; DeLone ir McLean, 2016; Fedorko et al., 2018; Dakduk et al., 2017). Elektroninė komercija - sudėtingas elektroninio verslo procesas, kurị norint ịgyvendinti reikia įvairių disciplinų žinių. Tad akivaizdu, jog turi būti sukurta pažangi sistema kurioje būtų integruoti ịvairių sąsajų kritiniai sėkmès veiksniai. Todèl remiantis patobulintu DeLone ir McLean elektroninè komercijos sėkmès modeliu buvo sukurtas naujas koncepcinis elektroninès komercijos sèkmès modelis (žr. 5 paveikslą). Šiame modelyje integruotas kartų skirtumo veiksnys, ị kurị turi būti atsižvelgiama siekiant sèkmingai vykdyti elektroninès komercijos veiklą.

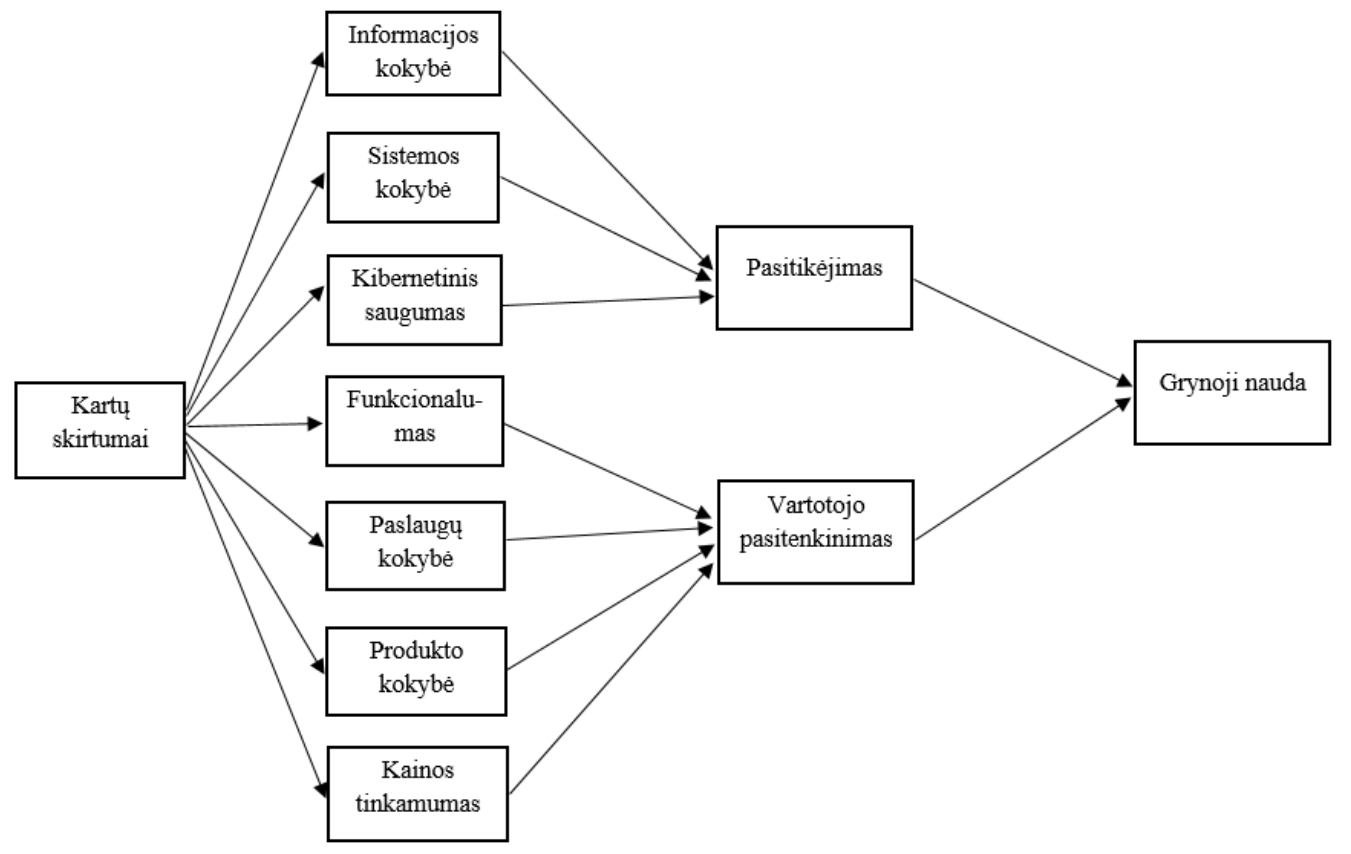

5 paveikslas. Elektroninės komercijos sėkmės koncepcinis modelis (sudaryta autorių)

Sudarytas teorinis elektroninès komercijos sėkmės veiksnių modelis, remiantis D\&M informacinių sistemų sėkmès modeliu. Sudarytas koncepcinis modelis apima vienuolika skirtingų veiksnių (kartų skirtumas, informacijos kokybė, sistemos kokybe், kibernetinis saugumas, funkcionalumas, paslaugu kokybė, produkto kokybė, kainos tinkamumas, pasitikejjimas, vartotojo pasitenkinimas, grynoji nauda) lemiančių elektroninès komercijos sẻkmę. Veiksniai parinkti remiantis literatūros analize bei anksčiau atliktais moksliniais tyrimais. Kaip dominuojantis veiksnys yra išskirtas kartų skirtumas. Pažymėtina tai, jog X ir Y kartų atstovai šiuo metu sukuria didžiausią perkamają galią internete, bet kaip teigiama literatūroje (Wang et al., 2019; Ramírez-Correa et al., 2019; Chakraborty ir Balakrishnan, 2017) jų poreikiai elektroninės komercijos platformoms skiriasi. Dèl šios priežasties svarbu atsižvelgti ị skirtingų kartų vartotojų poreikius ir jų savybes, norint sėkmingai vystyti elektroninės komercijos veiklą. Atkreipiamas dèmesys, kad literatūroje randama ribotas informacijos kiekis susijusęs su skirtingų kartų vartotojų poreikiais. Tiksliam šių poreikių identifikavimui būtinas papildomas tyrimas, pasitelkiant vartotojų apklausą. Tai tolimesné numatoma tyrimo kryptis, siekiant sudaryti efektyvų elektroninès komercijos sėkmės veiksnių modelį. 


\section{Išvados}

1. Išanalizavus mokslinès ir metodinès literatūros šaltinius buvo rasta ịvairių elektroninès komercijos apibrèžimų. Nustatyta, kad analizuojant elektroninès komercijos apibrěžtis, vieni autoriai akcentuoja naująsias technologijas, informacinių ir komunikacinių technologijų naudojimą igalinant verslo procesus, kiti - neribotų galimybių platformos naudojimo naudą bei verslo procesų grandinès efektyvumo augimą. Tuo tarpu autoriai skaito, jog tikslinga elektroninès komercijos terminą apibrèžti kaip modernų verslo modeli, paremtą interneto ir informacinių technologijų naudojimu, verslo procesams igalinti skaitmeninejje edrveje. Svarbu suprasti, jog elektroninès komercijos platformos tikslas igalinti verslo procesus ir kuo tikslingiau pasiekti vartotoją.

2. Atlikus elektroninès komercijos sèkmès veiksnių analizę buvo identifikuota, kad pagrindiniai faktoriai nulemiantys sėkmingą elektroninès komercijos veiklą yra: aplinkos faktorius ir technologiniai faktoriai (internetinis saugumas) bei klientų pasitenkinimas. Tolimesnèje analizèje buvo įvertintas D\&M IS sékmès modelis bei TAM ir TRA modeliai, kurie yra siejami su vartotojų elgsena skaitmeninèse platformose. Šių modelių analizè leido teigti, kad yra tam tikras ryšys tarp vartotojų nusistatymų dèl naujųjų technologijų veiksnumo ir noro jas naudoti. Remiantis šiuo ryšiu buvo pradèta skirtingo amžiaus vartotojų ypatumų, poreikių ir elgsenos analizè.

3. Remiantis literatūra, kurioje analizuojami skirtingų kartų vartotojų poreikiai bei elgsena buvo pastebėta, jog vyresnio amžiaus vartotojai linkę pirkti fizinèse parduotuvėse, nes jų pasitikèjimo lygis skaitmeninėmis platformomis daug žemesni nei kad jaunesnių vartotojų. Y kartos vartotojai yra užaugę technologinès eros laikotarpiu tad jie yra lankstesni ir sprendimus priimti jiems sekasi lengviau nei kad $\mathrm{X}$ kartos vartotojams. Šie faktoriai yra svarbūs siekiant sėkmès elektroninèje komercijoje.

4. Atlikus literatūros analizę ir remiantis statistiniais duomenis buvo nustatyta, kad didžiausią esamų vartotojų grupę sudaro dviejų skirtingų kartų atstovai. Remiantis literatūra nustatyta, kad skirtingų kartų vartotojų poreikiai skiriasi. Remiantis šia analize buvo sudarytas koncepcinis elektroninès komercijos sėkmès modelis, kuriame ịtrauktas kartų skirtumo veiksnys, kaip faktorius nulemiantis sėkmę elektroninejje komercijoje. Siekiant tiksliau nustatyti kokią ịtaką kartų skirtumas turi elektroninès komercijos sėkmei bus atliekama papildoma analizė, atliekant vartotojų apklausą, kadangi šiam veiksniui moksliniuose šaltiniuose skiriama nepakankamai dèmesio.

\section{Literatūra}

Abdullah, L., Ramli, R., Bakodah, H. O., \& Othman, M. (2019). Developing a causal relationship among factors of e-commerce: A decision making approach. Journal of King Saud University - Computer and Information Sciences (in Press), 1-8. https://doi.org/10.1016/j.jksuci.2019.01.002

Angelina, R. J., Hermawan, A., \& Suroso, A. I. (2019). Analyzing e-commerce success using DeLone and McLean model. Journal of Information Systems Engineering and Business Intelligence, 5(2), 156-162. https://doi.org/10.20473/jisebi.5.2.156-162

Azam, R. (2012). Global taxation of cross border e-commerce income. Virginia Tax Review, 31, 639.

Babenko, V., Kulczyk, Z., Perevozova, I., Syniavska, O., \& Davydova, O. (2019). Factors of development of international e-commerce in the context of globalization. CEUR Workshop Proceedings, 2422, 345-356.

Benjamin, Fang, J., Wen, C., George, B., \& Prybutok, V. R. (2016). Consumer heterogeneity, perceived value, and repurchase decision-making in online shopping: The role of gender, age, and shopping motives. Journal of Electronic Commerce Research, 17(2), 116-131. https://pdfs.semanticscholar.org/0bca/6352595935287ebaa523e96776d6b96e80cf.pdf

Bhalekar, P., Ingle, S., \& Pathak, K. (2015). The study of e-commerce. Asian Journal of Computer Science and Information Technology, 4(3), 25-27.

Bhat, D. S. A. (2016). A review paper on e-commerce. Asian Journal of Technology \& Management Research, 7(12), 0-13.

Chakraborty, T., \& Balakrishnan, J. (2017). Exploratory tendencies in consumer behaviour in online buying across gen X, gen Y and baby boomers. International Journal of Value Chain Management, 8(2), 135-150. https://doi.org/10.1504/IJVCM.2017.085483

Chaney, D., Touzani, M., \& Ben Slimane, K. (2017). Marketing to the (new) generations: summary and perspectives. Journal of Strategic Marketing, 25(3), 179-189. https://doi.org/10.1080/0965254X.2017.1291173

Choshin, M., \& Ghaffari, A. (2017). An investigation of the impact of effective factors on the success of e-commerce in smalland medium-sized companies. Computers in Human Behavior, 66, 67-74. https://doi.org/10.1016/j.chb.2016.09.026

Clement, J. (2019). Topic: E-commerce worldwide. https://www.statista.com/topics/871/online-shopping/

Cristofaro, M. (2019). E-business evolution: An analysis of mobile applications' business models. Technology Analysis and Strategic Management, 32(1), 88-103. https://doi.org/10.1080/09537325.2019.1634804

Dakduk, S., ter Horst, E., Santalla, Z., Molina, G., \& Malavé, J. (2017). Customer behavior in electronic commerce: A bayesian approach. Journal of Theoretical and Applied Electronic Commerce Research, 12(2), 1-20. https://doi.org/10.4067/S0718-18762017000200002 
Dasuki, S. I. (2018). Assessing e-learning systems success in Nigeria: An aplication of the Delone and Mclean Information Systems Success Model. Thecnology Education: Research, 17, 182-202. https://doi.org/10.28945/4077

DeLone, W. H., \& McLean, E. R. (2003). The DeLone and McLean model of information systems success: A ten-year update. Journal of Management Information Systems, 19(4), 9-30. https://doi.org/10.1080/07421222.2003.11045748

DeLone, W. H., \& McLean, E. R. (2016). Information systems success measurement. Foundations and Trends ${ }^{\circledR}$ in Information Systems, 2(1), 1-116. https://doi.org/10.1561/2900000005

Dhana Lakshmi, K. R., \& Shayena, S. (2018). E-commerce and it's impact on markets and retailers. International Journal of Research and Analytical Reviews (IJRAR), 5(3), 234-239. http://www.ijrar.org

Dyerson, R., Harindranath, G., \& Barnes, D. (2009). National Survey of SME's use of IT in four secters. Electronic Journal of Information Systems Evaluations, 12, 39-50.

Fang, J., Wen, C., George, B., \& Prybutok, V. R. (2016). Consumer heterogeneity, perceived value, and repurchase decisionmaking in online shopping: The role of gender, age, and shopping motives. Journal of Electronic Commerce Research, 17(2), 116-131. https://pdfs.semanticscholar.org/0bca/6352595935287ebaa523e96776d6b96e80cf.pdf

Fathian, M., Akhavana, P., \& Hoorali, M. (2008). E-readiness assessment of non-profit ICT SMEs in developing countyr: The case od Iran. Technovation, 28(9), 578-590. https://doi.org/10.1016/j.technovation.2008.02.002

Fedorko, I., Bacik, R., \& Gavurova, B. (2018). Technology acceptance model in e-commerce segment. Management and Marketing, 13(4), 1242-1256. https://doi.org/10.2478/mmcks-2018-0034

Franco, D. C. E., \& Regi, S. B. (2016). Advantages and challenges of e-commerce customers and businesses: In Indian perspective. International Journal of Research - Granthaalayah, 4(3), 7-13. http://granthaalayah.com/Articles/Vol4Iss3/02_IJRG16_SE03_02.pdf

Guzzo, T., Ferri, F., \& Grifoni, P. (2016). A model of e-commerce adoption (MOCA): Consumer's perceptions and behaviours. Behaviour and Information Technology, 35(3), 196-209. https://doi.org/10.1080/0144929X.2015.1132770

Jagannathan, V., Balasubramanian, S., \& Natarajan, T. (2018). An extension to the Delone and Mclean information systems success model and validation in the internet banking context. In M. Khosrow-Puour (Ed.), Encyclopedia of information science and technology (4th ed., pp. 49-60). https://doi.org/10.4018/978-1-5225-2255-3.ch004

Kabbaj, M. W. (2018). The major factors that contribute to e-commerce growth in the U.S and China: Analyses and adoption by Morocco. https://digitalcommons.salemstate.edu/honors_theses/204/

Kawasaki, G. (2004). The Art of the start: The time-tested, battle-hardened guide for anyone starting anything. https://www.amazon.com/Art-Start-Time-Tested-Battle-Hardened-Starting/dp/1591840562

Kinda, T. (2019). E-commerce as a potential new engine for growth in Asia. https://doi.org/10.5089/9781498317467.001

Lee, C., \& Lee, C. (2020). Generation difference of post-90s in the context of the rise of social commerce. Advances in Management and Applied Economics, 10(1), 15-33.

Lin, Y., Luo, J., Cai, S., Ma, S., \& Rong, K. (2016). Exploring the service quality in the e-commerce centext: A triadic view. Industrial Management \& Data Systems, 116(3), 388-415. https://doi.org/10.1108/IMDS-04-2015-0116

Mehra, J., \& Khurana, A. (2015). E-commerce: Opportunities and challenges. The International Journal of Business \& Management, 3(1), 182-186.

Miniwatss marketing group. (2019). World Internet Users Statistics and 2019 World Population Stats. https://www.internetworldstats.com/stats.htm

Pappas, I. O. (2018). User experience in personalized online shopping: A fuzzy-set analysis. European Journal of Marketing, 52(7/8), 1679-1703. https://doi.org/10.1108/EJM-10-2017-0707

Ramadiani, Azainil, Haryaka, U., Agus, F., \& Kridalaksana, A. H. (2017). User satisfaction model for e-learning using smartphone. Procedia Computer Science, 116, 373-380. https://doi.org/10.1016/j.procs.2017.10.070

Ramanathan, R., Ramanathan, U., \& Hsia, H.-L. (2012). The impact of e-commerce on Taiwanese SMEs: Marketing and operations effects. International Journal of Production Economics, 140(2), 934-943. https://doi.org/10.1016/j.ijpe.2012.07.017

Ramírez-Correa, P. E., Grandón, E. E., \& Arenas-Gaitán, J. (2019). Assessing differences in customers’ personal disposition to e-commerce. Industrial Management and Data Systems, 119(4), 792-820. https://doi.org/10.1108/IMDS-07-2018-0280

Roky, H., \& Meriouh, Y. Al. (2015). Evaluation by users of an industrial information system (XPPS) based on the DeLone and McLean model for IS success. Procedia Economics and Finance, 26, 903-913. https://doi.org/10.1016/S2212-5671(15)00903-X

Rigby, C. (2019). UK business online sales grow at fastest rate on record. https://internetretailing.net/

Ross-Cortes, E., Ramírez-Correa, P., \& Rondan-Cataluña, F. J. (2016). Estudio exploratorio sobre las diferencias generacionales en la transmisión y recepción de opiniones en línea por parte de los compradores en el contexto de los servicios de redes sociales. Revista ESPACIOS, 37(17), 12.

Santos, V. F. dos, Sabino, L. R., Morais, G. M., \& Goncalves, C. A. (2017). E-commerce: A short history follow-up on possible trends. International Journal of Business Administration, 8(7), 130. https://doi.org/10.5430/ijba.v8n7p130

Shaw, M. J. (2014). Electronic commerce: State of the art. Handbook on Electronic Commerce, 4(4), 3-24. https://doi.org/10.1007/978-3-642-58327-8_1 
Solangi, Y. A., Solangi, Z., Raza, A., Madihah Bt, M. B. S., bin Hamzah, M. S., \& Shah, A. (2018). Social commerce in ebusiness of Pakistan: Opportunities, challenges and solutions. In International Conference on Information and Communication Technology for the Muslim World (ICT4M 2018), Kuala Lumpur, pp. 126-131. https://doi.org/10.1109/ICT4M.2018.00032

Vadwala, A. Y., \& Vadwala, M. S. (2017). E-commerce: Merits and demerits a review paper. International Journal of Trend in Scientific Research and Development, 1(4). https://doi.org/10.31142/ijtsrd106

Varela, M. L. R., Araújo, A. F., Vieira, G. G., Manupati, V. K., \& Manoj, K. (2017). Integrated framework based on critical success factors for e-commerce. Journal of Information Systems Engineering \& Management, 2(1), 1-9. https://doi.org/10.20897/jisem.201704

Wang, Y. S. (2008). Assessing e-commerce systems success: a respecification and validation of the DeLone and McLean model of IS success. Information Systems Journal, 18(5), 529-557. https://doi.org/10.1111/j.1365-2575.2007.00268.x

Wang, Y. S., Tseng, T. H., Wang, W. T., Shih, Y. W., \& Chan, P. Y. (2019). Developing and validating a mobile catering app success model. International Journal of Hospitality Management, 77, 19-30. https://doi.org/10.1016/j.ijhm.2018.06.002

Ward, B. T., Sipior, J. C., \& Volonino, L. (2016). Internet jurisdiction for e-commerce. Journal of Internet Commerce, 15(1), 1-17. https://doi.org/10.1080/15332861.2015.1109988

Yadiati, W., \& Meiryani. (2019). The role of information technology in E-Commerce. International Journal of Scientific and Technology Research, 8(1), 173-176.

\title{
CRITICAL SUCCESS FACTORS OF THE E-COMMERCE PROJECTS
}

\section{Jolanta SABAITYTE், Guoda ČERNIAUSKAITE்}

\begin{abstract}
The number of Internet users worldwide is growing rapidly. Over the past 19 years, this number has grown from $360,983,512$ to 4,536,248,808 users, showing extremely rapid growth. E-commerce is becoming a potential area for business development and provides significant added value to the global economy. Increasing supply to the consumer creates an area for being fastidious. This increases competition between e-commerce platforms and makes it harder to stay successful. The purpose of this paper is to identify the factors that determine the success of e-commerce projects and to create a conceptual model of e-commerce success. Scientific literature analysis was performed to identify the main succcess factors. After evaluating the existing success factors and success models, shortcomings were identified and an e-commerce success model was developed, which incorporates generational difference as a factor that determines user choice.
\end{abstract}

Keywords: information technologies, e-commerce, e-commerce profects, e-commerce success model, success factors. 